Bull. Chem. Soc. Ethiop. 2012, 26(1), 95-101.

Printed in Ethiopia

DOI: http://dx.doi.org/10.4314/bcse.v26i1.10

SSN 1011-3924

(c) 2012 Chemical Society of Ethiopia

\title{
SYNTHESIS, MAGNETIC AND SPECTROSCOPIC STUDIES of Ni(II), Cu(II), Zn(II) and Cd(II) COMPLEXES OF A NEWLY SCHIFF BASE DERIVED FROM 5-BROMO- 2-HYDROXYBEZYLIDENE)-3,4,5-TRIHYDROXYBENZOHYDRAZIDE)
}

\author{
Abeer A. Alhadi ${ }^{1}$, Shayma A. Shaker ${ }^{2 *}$, Wagee A. Yehye ${ }^{1}$, Hapipah Mohd Ali $^{1}$ and Mahmood \\ A. Abdullah ${ }^{3}$ \\ ${ }^{1}$ Department of Chemistry, University of Malaya, 50603 Kuala Lumpur, Malaysia \\ ${ }^{2}$ Department of Engineering Sciences and Mathematics, College of Engineering, Universiti \\ Tenaga Nasional, KM 7 Jalan Kajang-Puchong, 43009 Kajang, Selangor, Malaysia \\ ${ }^{3}$ Department of Molecular Medicine, University of Malaya, 50603 Kuala Lumpur, Malysia
}

(Received May 17, 2011; revised October 3, 2011)

\begin{abstract}
A new hydrazide Shiff base ligand GHL1 (5-bromo-2-hydroxybezylidene)-3,4,5trihydroxybenzohydrazide) was prepared by refluxing of trihydroxybenzhydrazide with an ethanolic of 5-bromo2-hydroxybenzaldehyde. The ligand reacted with $\mathrm{Ni}(\mathrm{II}), \mathrm{Cu}$ (II), $\mathrm{Zn}$ (II) and $\mathrm{Cd}$ (II) (acetate salts). All the complexes were characterized by elemental analysis, molar conductivity, TGA, UV-Vis and FT-IR spectral studies. All the complexes have octahedral geometry except $\mathrm{Ni}$ (II) complex which has tetrahedral geometry.
\end{abstract}

KEY WORDS: Hydrazone complexes, Schiff base ligand, Spectral studies

\section{INTRODUCTION}

The tridentate of benzhydrazone derivatives ligand containing ONO donor atoms can be synthesized easily by reacting benzhydrazide with any aldehyde or ketone [1]. The presence of donor atoms in the ligand will plays an important role in the formation of a stable chelate ring and this situation facilitates the complexation process [2]. Moreover, the synthesis, spectroscopic characterization and reaction of transition metal with hydrazone ligands have shown wide spectra of biological and pharmaceutical activities such as possess antimicrobial, antibacterial, antifungal, anti-inflammatory, anticonvulsant, antitubercular, antiviral, antioxidative effects and inhibition of tumor growth [3-5]. The bioinorganic chemistry paid great attention to the Schiff base complexes because many of these complexes have biologically important species [6]. So, the synthesis of new ligands and complexes would be important step in the development of coordination chemistry which exhibit novel properties and reactivity [5]. In searching for complexes of transition metals with novel coordination spheres, it was found that the tridentate coordination is made of the hydrazone ligands. This makes them suitable chelating agents for metal ions and preferring the octahedral geometry [7, 8]. Thus in this paper the synthesis and characterization of $\mathrm{Ni}(\mathrm{II}), \mathrm{Cu}$ (II), $\mathrm{Zn}$ (II) and $\mathrm{Cd}(\mathrm{II})$ complexes with hydrazide derivative are described.

\section{EXPERIMENTAL}

\section{Materials and techniques}

The chemicals used in this study were all pure grade (Ni(II) acetate, $\mathrm{Cu}$ (II) acetate, $\mathrm{ZnCl}_{2}, \mathrm{Cd}$ (II) acetate, gallic hydrazide, 2-acetylpyridine, ethanol, DMSO, DMF, triethylamine and $\mathrm{KBr}$ ) from Merck.

*Corresponding author. E-mail: drshaimaa611@yahoo.com 
Infrared spectra were obtained using $\mathrm{KBr}$ discs $\left(4000-400 \mathrm{~cm}^{-1}\right)$ on Perkin-Elmer FT-IR spectrometer. The electronic spectra were carried out using a Cary 50Conc. UV-Visible spectra were recorded using spectrophotometer in DMSO solution $10^{-3} \mathrm{M}$. Thermal analysis studies of the complex were performed on Perkin-Elmer Pyris Diamond DTA/TG Thermal System under nitrogen atmosphere at a heating rate of $10{ }^{\circ} \mathrm{C} / \mathrm{min}$ from $30-900{ }^{\circ} \mathrm{C}$. Elemental analysis $(\mathrm{C}, \mathrm{H}$, $\mathrm{N})$ were performed by using a Flash EA 1112 Series elemental analyzer.

Synthesis of gallic hydrazide

3,4,5-Trihydroxybenzoate $(1.84 \mathrm{~g})$ and $(0.01 \mathrm{M}) \mathrm{C}_{8} \mathrm{H}_{8} \mathrm{O}_{5}$ were added, respectively to $9 \mathrm{~mL}$ of hydrazine hydrate, after stirred $30 \mathrm{~min}$. The product was immediately precipitate, filtered off, washed and recrystalized with ethanol and dried under vacuum [9].

Synthesis of the ligand GHL1

5-Bromo-2-hydroxybenzylidene)-3,4,5-trihydroxybenzohydrazide was prepared by adding trihydroxybenzhydrazide $(0.65 \mathrm{~g}, 3.5 \mathrm{mmol})$ to an ethanolic solution of 5-bromo-2hydroxybenzaldehyde $(0.70 \mathrm{~g}, 3.5 \mathrm{mmol})$. The mixture was refluxed about 12 hour and left it over night. The colorless crystals were obtained upon slow evaporation, filtered off and dried under vaccum [10].

\section{Synthesis of the metal complexes}

An ethanolic solution of 5-bromo-2-hydroxybenzylidene)-3,4,5-trihydroxybenzohydrazide ( 0.35 $\mathrm{g}, 0.8 \mathrm{mmol}$ ) was added to $50 \mathrm{~mL}$ of an aqueous solution of the metal salts with three drops of triethylamine. The mixture was stirred and refluxed for 5 hours. The solid product was precipitate, filtered washed and recrystallized from DMSO and dried in desiccator.

\section{RESULTS AND DISCUSSION}

The prepared complexes were found to be solids, soluble in dimethylsulfoxide. The elemental analysis shown in Table 1 indicates that all the complexes were in good agreement with the values calculated from the proposed formula

Table 1. Physical properties and analytical data of the ligand and its complexes.

\begin{tabular}{|l|c|c|c|c|c|c|}
\hline Compound & \multicolumn{2}{|c|}{ Elemental analysis, calculated (found) \% } & Color & \multirow{2}{\text{Yeild}}{} & $\begin{array}{c}\text { M.p. } \\
(\%)\end{array}$ \\
\cline { 2 - 4 } & $\mathrm{C}$ & $\mathrm{H}$ & $\mathrm{N}$ & & $(\%)$ \\
\hline $\mathrm{GHL} 1$ & $41.12(41.47)$ & $4.99(5.14)$ & $5.99(6.76)$ & White & 70 & 255 \\
\hline$\left[\mathrm{Ni}(\mathrm{GHL} 1)_{2}\right]\left(\mathrm{CH}_{3} \mathrm{COO}\right)_{2} \cdot \mathrm{H}_{2} \mathrm{O}$ & $46.7(45.6)$ & $4.18(3.8)$ & $6.2(6.8)$ & Yellow & 65 & 260 \\
\hline$\left[\mathrm{Cu}(\mathrm{GHL} 1)_{2}\right] .3 \mathrm{H}_{2} \mathrm{O}$ & $47.65(45.37)$ & $3.68(3.34)$ & $7.94(6.41)$ & Green & 70 & 240 \\
\hline$\left[\mathrm{Zn}(\mathrm{GHL} 1)_{2}\right] .3 \mathrm{H}_{2} \mathrm{O}$ & $48.5(47.7)$ & $3.79(4.03)$ & $8.09(7.53)$ & White & 70 & 335 \\
\hline$\left[\mathrm{Cd}(\mathrm{GHL} 1)\left(\mathrm{CH}_{3} \mathrm{COO}\right)_{2}\right] .2 \mathrm{H}_{2} \mathrm{O}$ & $30.50(32.85)$ & $2.99(2.95)$ & $4.88(4.98)$ & White & 60 & 150 \\
\hline
\end{tabular}

Electronic spectra and magnetic studies

The electronic spectrum of the ligand GHL1 shows two bands at 307 and $340 \mathrm{~nm}$ due to the $\mathrm{n} \rightarrow \pi^{*}$ transition of the chromophore $(-\mathrm{C}=\mathrm{N}-\mathrm{NH}-\mathrm{CO})$. In the spectra of the complexes, these bands were shifted to the lower frequencies which indicate that the imin nitrogen atom and the oxygen atom were involved in coordination with the metal ions $[3,7]$.

Bull. Chem. Soc. Ethiop. 2012, 26(1) 
The electronic spectrum of $\mathrm{Ni}$ (II) complex displayed two bands in the visible region observed at 422 and $626 \mathrm{~nm}$ which are assigned to the electronic transitions ${ }^{3} \mathrm{~T}_{1(\mathrm{~F})} \rightarrow{ }^{3} \mathrm{~T}_{1(\mathrm{P})}\left(v_{3}\right)$ and ${ }^{3} \mathrm{~T}_{1(\mathrm{~F})} \rightarrow{ }^{3} \mathrm{~T}_{2(\mathrm{~F})}\left(v_{1}\right)$, respectively. The band $\left(v_{2}\right)$ is attributed to the transition ${ }^{3} \mathrm{~T}_{1(\mathrm{~F})} \rightarrow{ }^{3} \mathrm{~A}_{2}(\mathrm{~F})$ which corresponds to the charge transfer (C.T.) at $385 \mathrm{~nm}$ [11]. The calculated value of the ligand field parameter 10Dq is $19967 \mathrm{~cm}^{-1}$ for $\left(v_{1}\right)$. Thus, the interelectronic repulsion parameter $\mathrm{B}$ was calculated and found to be $116 \mathrm{~cm}^{-1}$ for Ni(II) complex, this value is less than the free $\mathrm{Ni}^{2+}$ ion value of $1040 \mathrm{~cm}^{-1}$ which was due to overlapping and delocalization of electrons over the molecular orbital that encompasses both the metal and ligands. Moreover, the nephelauxetic ratio $\beta=\mathrm{B} / \mathrm{B}^{\circ}=0.11$ indicates appreciable covalent character in this complex $[3-6,8,12]$. So, the magnetic moment value is 3.4 B.M., which demonstrates that the $\mathrm{Ni}(\mathrm{II})$ complex is paramagnetic and has a high spin tetrahedral configuration with ${ }^{3} \mathrm{~T}_{1(\mathrm{~F})}$ ground state $[3,6,13,14]$. Furthermore, the molar conductivity of $10^{-3} \mathrm{M}$ in DMSO at room temperature is $73 \mathrm{ohm}^{-1} \mathrm{~cm}^{2}$ $\mathrm{mol}^{-1}$ indicates that the $\mathrm{Ni}(\mathrm{II})$ complex is electrolyte [15].

The electronic spectrum of the $\mathrm{Cu}$ (II) complex displayed strong bands in the range of 324$340 \mathrm{~nm}$ which can be assigned to $\mathrm{n} \rightarrow \pi^{*}$, charge transfer LMCT band exhibited in the range of 400-415 nm. Thus, the spectrum showed d-d electronic transition at $607 \mathrm{~nm}$ which assigned to ${ }^{2} \mathrm{Eg}(\mathrm{D}) \rightarrow{ }^{2} \mathrm{~T}_{2} \mathrm{~g}_{(\mathrm{D})}$. The broadness of the band is due to the ligand field and the Jahn-Teller effect. These absorption prefer the distorted octahedral geometry for the $\mathrm{Cu}$ (II) ion. Moreover, the magnetic moment for the $\mathrm{Cu}$ (II) complex is $1.9 \mathrm{~B}$.M. which within the expected value for one electron. Furthermore, the complex is non-electrolyte as the molar conductance was found to be at $0.87 \mathrm{ohm}^{-1} \mathrm{~cm}^{2} \mathrm{~mol}^{-1}$ in $10^{-3} \mathrm{M}$ in DMSO [5, 11, 16-18].

Finally, the diamagnetic $\mathrm{Zn}$ (II) and Cd(II) complexes show absorption bands at 325 and 285 , $320 \mathrm{~nm}$, respectively. These bands are attributed to the charge transfer MLCT as the electronic configuration of these complexes confirmed the absence of any d-d transition $[16,19,20]$. All data and remarks are found in Table 2.

Table 2. The electronic spectra of free ligands and their complexes.

\begin{tabular}{|c|c|c|c|c|c|}
\hline Compound & $\begin{array}{c}\lambda_{\max } \\
\mathrm{nm}\end{array}$ & $\begin{array}{l}\text { Wavenumber } \\
\mathrm{cm}^{-1}\end{array}$ & $\begin{array}{c}\varepsilon_{\max } \\
\mathrm{Lmol}^{-1} \mathrm{~cm}^{-1}\end{array}$ & Assignment & $\begin{array}{c}\mu_{\text {eff }} \\
\text { calc.(found) } \\
\text { B.M. }\end{array}$ \\
\hline \multirow[t]{2}{*}{ GHL1 } & 307 & 32573 & 1845 & $\mathrm{n} \rightarrow \pi^{*}$ & \multirow[t]{2}{*}{-} \\
\hline & 340 & 29411 & 2118 & $\mathrm{n} \rightarrow \pi^{*}$ & \\
\hline \multirow[t]{3}{*}[\mathrm{Ni}(\mathrm{GHL}1)_{2}]{$\left(\mathrm{CH}_{3} \mathrm{COO}\right)_{2} .4 \mathrm{H}_{2} \mathrm{O}$} & 385 & 25974 & 1097 & ${ }^{3} \mathrm{~T}_{1(\mathrm{~F})} \rightarrow{ }^{3} \mathrm{~A}_{2(\mathrm{~F})}$ & \multirow{3}{*}{$\begin{array}{c}2.828 \\
(3.4)\end{array}$} \\
\hline & 422 & 23696 & 16 & ${ }^{3} \mathrm{~T}_{1(\mathrm{~F})} \rightarrow{ }^{3} \mathrm{~T}_{1(\mathrm{P})}$ & \\
\hline & 626 & 15974 & 11 & ${ }^{3} \mathrm{~T}_{1(\mathrm{~F})} \rightarrow{ }^{3} \mathrm{~T}_{2(\mathrm{~F})}$ & \\
\hline \multirow[t]{5}{*}[\mathrm{Cu}(\mathrm{GHL}1)_{2}]{$\cdot 3 \mathrm{H}_{2} \mathrm{O}$} & 324 & 30864 & 391 & $\mathrm{n} \rightarrow \pi^{*}$ & \multirow{5}{*}{$\begin{array}{l}1.732 \\
(1.9)\end{array}$} \\
\hline & 340 & 29411 & 441 & $\mathrm{n} \rightarrow \pi^{*}$ & \\
\hline & 400 & 25000 & 564 & C.T & \\
\hline & 415 & 24096 & 563 & C.T & \\
\hline & 607 & 16474 & 31 & ${ }^{2} \mathrm{Eg}_{(\mathrm{D})} \rightarrow{ }^{2} \mathrm{~T}_{2} \mathrm{~g}_{(\mathrm{D})}$ & \\
\hline$\left[\mathrm{Zn}(\mathrm{GHL} 1)_{2}\right] .3 \mathrm{H}_{2} \mathrm{O}$ & 325 & 30769 & 113 & C.T $(\mathrm{M} \rightarrow \mathrm{L})$ & diamagnetic \\
\hline \multirow[t]{2}{*}[\mathrm{Cd}(\mathrm{GHL}1)(\mathrm{CH}_{3}\mathrm{COO})_{2}]{$\cdot 2 \mathrm{H}_{2} \mathrm{O}$} & 285 & 35087 & 1200 & $\pi \rightarrow \pi^{*}$ & \multirow[t]{2}{*}{ diamagnetic } \\
\hline & 320 & 31250 & 324 & C.T $(\mathrm{M} \rightarrow \mathrm{L})$ & \\
\hline
\end{tabular}


Infrared spectra studies

The infrared spectrum of the ligand GHL1 showed strong bands at 3569 and $3223 \mathrm{~cm}^{-1}$ which are due to the $v(\mathrm{OH})$ and $v(\mathrm{NH})$, respectively. Thus, the $v(\mathrm{C}=\mathrm{N})$ band of the ligand was observed at $1637 \mathrm{~cm}^{-1}$ and this band was shifted to the lower frequencies by $48-19 \mathrm{~cm}^{-1}$ in the spectra of the complexes. Furthermore, the complexes exhibited weak bands between 550-575 $\mathrm{cm}^{-1}$ which are attributed to $v(\mathrm{M}-\mathrm{N})$. This indicates that the ligand was coordinated with the metal ions through the $\mathrm{N}$ atom. However, the spectrum of the ligand showed strong band at $1545 \mathrm{~cm}^{-1}$ which attributed to $v(\mathrm{C}=\mathrm{O})$. Actually, this band was shifted to the lower frequencies by $20-4 \mathrm{~cm}^{-1}$ in the spectra of the complexes. While, the $v(\mathrm{C}-\mathrm{O})$ appeared at $1089 \mathrm{~cm}^{-1}$ in the spectra of the free ligand which was shifted to the higher frequencies by $85-104 \mathrm{~cm}^{-1}$. Moreover, the spectra of the complexes exhibited weak bands between $440-481 \mathrm{~cm}^{-1}$ which is attributed to the $v(\mathrm{M}-\mathrm{O})$. This indicates that the GHL1 is tridentate ligand which is coordinated with the metal ions through $\mathrm{ONO}$ atoms.

The asymmetrical and symmetrical vibration of $v\left(\mathrm{COO}^{-}\right)$were noticed at 1450 and 1346 $\mathrm{cm}^{-1}$, respectively in the spectrum of the Cd(II) complex. So, the complex was also exhibited weak band at $481 \mathrm{~cm}^{-1}$ which is due to $v(\mathrm{M}-\mathrm{O})$. This indicates that the acetate group is coordinated with $\mathrm{Cd}(\mathrm{II})$ ion through the two of $\mathrm{O}$ atoms [21-23]. Characteristic vibrations and assignments of free ligand and its complexes as $\mathrm{KBr}$ pellets are listed in Table 3.

Table 3. Characteristic IR bands $\left(\mathrm{cm}^{-1}\right)$ of the ligand and its metal complexes.

\begin{tabular}{|l|c|c|c|c|c|c|c|c|}
\hline Compound & $v(\mathrm{OH})$ & $v(\mathrm{NH})$ & $v(\mathrm{C}=\mathrm{N})$ & $v(\mathrm{C}=\mathrm{O})$ & $v(\mathrm{C}-\mathrm{O})$ & $v(\mathrm{~N}-\mathrm{N})$ & $v(\mathrm{M}-\mathrm{N})$ & $v(\mathrm{M}-\mathrm{O})$ \\
\hline $\mathrm{GHL} 1$ & 3569 & 3223 & 1637 & 1545 & 1089 & 1049 & - & - \\
\hline$\left[\mathrm{Ni}(\mathrm{GHL} 1)_{2}\right]\left(\mathrm{CH}_{3} \mathrm{COO}\right)_{2} \cdot \mathrm{H}_{2} \mathrm{O}$ & 3445 & 3222 & 1599 & 1525 & 1177 & 1028 & 575 & 452 \\
\hline$\left[\mathrm{Cu}(\mathrm{GHL} 1)_{2}\right] \cdot 3 \mathrm{H}_{2} \mathrm{O}$ & 3377 & 3220 & 1618 & 1541 & 1193 & 1045 & 556 & 440 \\
\hline$\left[\mathrm{Zn}(\mathrm{GHL} 1)_{2}\right] \cdot 3 \mathrm{H}_{2} \mathrm{O}$ & 3475 & 3247 & 1589 & 1530 & 1179 & 1023 & 559 & 453 \\
\hline$\left[\mathrm{Cd}(\mathrm{GHL} 1)\left(\mathrm{CH}_{3} \mathrm{COO}\right)_{2}\right] \cdot 2 \mathrm{H}_{2} \mathrm{O}$ & 3414 & 3241 & 1609 & 1540 & 1174 & 1055 & 550 & 481 \\
\hline
\end{tabular}

Thermal studies

The weight loss was measured from 40 to $950{ }^{\circ} \mathrm{C}$. The weight losses for each chelate were calculated for the corresponding temperature ranges are shown in Table 4 . The metal percentages calculated from metal oxide or metal residues were compared with those determined by the analytical metal content determination [24].

The Ni(II) complex was stable up to $40{ }^{\circ} \mathrm{C}$ and its decomposition started at this temperature and was completed at $952{ }^{\circ} \mathrm{C}$. A mass loss occurred within the temperature range $(40-200)^{\circ} \mathrm{C}$ corresponding to the loss of four hydrated water molecules. The Ni(II) complex decomposed and produced $\mathrm{NiO}$ as residue [found(calculated)\%: 8.945(8.28)] in four steps in the temperature range 40-200, 200-350, 350-500 and 500-795 ${ }^{\circ} \mathrm{C}$, respectively. In the decomposition process of $\mathrm{Ni}$ (II) complex, the mass losses corresponded to $4\left(\mathrm{H}_{2} \mathrm{O}\right), 2\left(\mathrm{CH}_{3} \mathrm{CO}_{2}\right), 2(\mathrm{BrPh}-\mathrm{CH})$ and $\left.2\left[(\mathrm{OH})_{3} \mathrm{Ph}-\mathrm{CON}_{2} \mathrm{H}\right)\right]$, respectively [24].

The $\mathrm{Cu}(\mathrm{II})$ complex was stable up to $35^{\circ} \mathrm{C}$ and its decomposition started at this temperature and was completed at $608{ }^{\circ} \mathrm{C}$. A mass loss occurred within the temperature range $36-266{ }^{\circ} \mathrm{C}$ corresponding to the loss of three hydrated water molecules [24]. The $\mathrm{Cu}$ (II) complex decomposed and produced $\mathrm{Cu}$ as a residue [found(calculated)\%: 7.21(8.4)] in three steps in the temperature range of 36-266, 271-446, and $452-608{ }^{\circ} \mathrm{C}$, respectively. In the decomposition process of $\mathrm{Cu}(\mathrm{II})$ complex, the mass losses corresponded to $3 \mathrm{H}_{2} \mathrm{O}, 2\left(\mathrm{C}_{7} \mathrm{H}_{5} \mathrm{~N}_{2} \mathrm{OBr}\right)$ and $2\left(\mathrm{C}_{6} \mathrm{H}_{5} \mathrm{O}_{3}\right)$, respectively. 
The $\mathrm{Zn}$ (II) complex was stable up to $35.00{ }^{\circ} \mathrm{C}$ and its decomposition started at $35.04{ }^{\circ} \mathrm{C}$ and was completed at $710.61{ }^{\circ} \mathrm{C}$. A mass loss occurred within the temperature range 35.04-315.21 ${ }^{\circ} \mathrm{C}$ corresponding to the loss of three hydrated water molecules [24]. The $\mathrm{Zn}$ (II) complex decomposed and produced $\mathrm{Zn}$ as a residue [found(calculated)\%: 8.85(9.43)] in four steps in the temperature range $35.04-315.21,318.53-341.79,347.33-592.10$ and $596.53-710.61{ }^{\circ} \mathrm{C}$, respectively. In the decomposition process of $\mathrm{Zn}$ (II) complex, the mass losses corresponded to $3 \mathrm{H}_{2} \mathrm{O},\left(\mathrm{C}_{6} \mathrm{H}_{5} \mathrm{O}_{3}\right)_{2} \mathrm{CO}$ and $(\mathrm{BrPhCHNNH})_{2} \mathrm{CO}$, respectively.

The $\mathrm{Cd}$ (II) complex was stable up to $40.00{ }^{\circ} \mathrm{C}$ and its decomposition started at this temperature and was completed at $950{ }^{\circ} \mathrm{C}$. A mass loss has occurred within the temperature range of $40.00-140.0^{\circ} \mathrm{C}$ corresponding to the loss of two hydrated water molecules. The $\mathrm{Cd}(\mathrm{II})$ complex decomposed and produced $\mathrm{CdO}$ residue [found(calculated)\%: $12.2(19.2)$ ] in four steps in the temperature range of 40.00-140.0, 145.0-250.0, 300.0-470 and 470.0-950.0 ${ }^{\circ} \mathrm{C}$, respectively. In the decomposition process of $\mathrm{Cd}$ (II) complex, the mass losses corresponded to $2 \mathrm{H}_{2} \mathrm{O}, 2 \mathrm{H}_{2} \mathrm{O},\left(2 \mathrm{CH}_{3} \mathrm{CO}_{2}, \mathrm{~N}_{2}\right)$ and $\left(\mathrm{BrPhCH}_{2}+\mathrm{C}_{7} \mathrm{H}_{6} \mathrm{O}_{4}\right)$, respectively. The TGA curves of these complexes, $6.411 \%, 6.322 \%, 8.147 \%$ and $6.060 \%$, respectively, indicate weight loss. This shows that the complexes contain $4,4,3$ and 3 moles of water per complex molecule, respectively. The IR spectra of the complexes are characterized by appearance of a broad band in the region of $3416-3377 \mathrm{~cm}^{-1}$, due to the $v(-\mathrm{OH})$ of the water [25]. This water was not identified by the elemental analyses, therefore location of the water molecules were outside the complex structure. The curves of TGA concerning the solid complexes reflected the experimental results for the residual amount of loss of mass which were in good agreement with the calculated results. The intermediate and the final products of the thermal decomposition of the complexes were identified by IR spectra as well. The thermal decomposition processes of the complex were summarized in Table 4.

Table 4. Thermal analysis data for some metal complexes of GHL1.

\begin{tabular}{|c|c|c|c|c|c|}
\hline Complex & Stage & $\begin{array}{c}\text { Temperature } \\
(\mathrm{C})\end{array}$ & $\begin{array}{c}\text { Weight loss (\%) } \\
\text { found (calc.) }\end{array}$ & Assignment & $\begin{array}{l}\text { Residue (\%) } \\
\text { found(calc.) }\end{array}$ \\
\hline \multirow[t]{4}{*}[\mathrm{Ni}(\mathrm{GHL}1)_{2}]{$\left(\mathrm{CH}_{3} \mathrm{COO}\right)_{2} \cdot \mathrm{H}_{2} \mathrm{O}$} & 1 & $40.0-200.0$ & $8.15(7.98)$ & $4 \mathrm{H}_{2} \mathrm{O}$ & \multirow{4}{*}{$\begin{array}{c}\mathrm{NiO} \\
8.9(8.3)\end{array}$} \\
\hline & 2 & $200.0-350.0$ & $11.98(13.09)$ & $2\left(\mathrm{CH}_{3} \mathrm{CO}_{2}\right)$ & \\
\hline & 3 & $350.0-500.0$ & $36.95(37.20)$ & $(\mathrm{Br}-\mathrm{Ph}-\mathrm{CH})_{2}$ & \\
\hline & 4 & $500.0-795.0$ & $33.97(33.95)$ & {$[3(\mathrm{OH}) \mathrm{Ph}-\mathrm{CONHN}]_{2}$} & \\
\hline \multirow[t]{3}{*}[\mathrm{Cu}(\mathrm{GHL}1)_{2}]{$.3 \mathrm{H}_{2} \mathrm{O}$} & 1 & $36.1-266.2$ & $5.82(7.01)$ & $3 \mathrm{H}_{2} \mathrm{O}$ & \multirow{3}{*}{$\begin{array}{c}\mathrm{Cu} \\
7.21(8.03)\end{array}$} \\
\hline & 2 & $270.6-446.4$ & $65.12(64.82)$ & $2\left(\mathrm{C}_{7} \mathrm{H}_{5} \mathrm{~N}_{2} \mathrm{OBr}\right)$ & \\
\hline & 3 & $452.0-607.9$ & $21.85(20.62)$ & $2\left(\mathrm{C}_{6} \mathrm{H}_{5} \mathrm{O}_{3}\right)$ & \\
\hline \multirow[t]{3}{*}[\mathrm{Zn}(\mathrm{GHL}1)_{2}]{$\cdot 3 \mathrm{H}_{2} \mathrm{O}$} & 1 & $35.0-315.2$ & $6.05(7.10)$ & $3 \mathrm{H}_{2} \mathrm{O}$ & \multirow{3}{*}{$\begin{array}{c}\mathrm{Zn} \\
8.8(9.4)\end{array}$} \\
\hline & 2 & $318.5-341.7$ & $19.17(20.23)$ & BrPhCHNNH & \\
\hline & 3 & $347.3-592.1$ & $30.85(32.25)$ & (BrPhCHNNH)CO & \\
\hline \multirow[t]{4}{*}[\mathrm{Cd}(\mathrm{GHL}1)(\mathrm{CH}_{3}\mathrm{COO})_{2}]{$\cdot \mathrm{H}_{2} \mathrm{O}$} & 1 & $40.00-140.0$ & $6.40(5.38)$ & $2 \mathrm{H}_{2} \mathrm{O}$ & \multirow{4}{*}{$\begin{array}{c}\mathrm{CdO} \\
12.2(19.2)\end{array}$} \\
\hline & 2 & $145.0-250.0$ & $11.10(10.76)$ & $2 \mathrm{H}_{2} \mathrm{O}$ & \\
\hline & 3 & $300.0-470.0$ & $22.76(21.83)$ & $\left(2 \mathrm{CH}_{3} \mathrm{CO}_{2}^{-}+\mathrm{N}_{2}\right)$ & \\
\hline & 4 & $470.0-950.0$ & $47.58(47.98)$ & $\mathrm{BrPhCH}_{2}+\mathrm{C}_{7} \mathrm{H}_{5} \mathrm{O}_{4}$ & \\
\hline
\end{tabular}

\section{CONCLUSIONS}

In this paper synthesis and spectroscopic characterization of hydrazone derivative ligand and their $\mathrm{Ni}(\mathrm{II}), \mathrm{Cu}(\mathrm{II}), \mathrm{Zn}(\mathrm{II})$ and $\mathrm{Cd}(\mathrm{II})$ complexes were presented. The elemental analysis, magnetic susceptibility, FT-IR, UV-Vis, TGA spectral observation suggest the tetrahedral geometry around $\mathrm{Ni}$ (II) complex as shown in Figure 1 and octahedral geometry around $\mathrm{Cu}(\mathrm{II})$, 
$\mathrm{Zn}$ (II) and $\mathrm{Cd}$ (II) complexes as shown in Figure 2. The conductance measurement of $\mathrm{Ni}$ (II) complex is electrolyte. The $\mathrm{Cd}(\mathrm{II}), \mathrm{Ni}(\mathrm{II}), \mathrm{Zn}$ (II) and $\mathrm{Cu}$ (II) complexes are thermally stable up to $35{ }^{\circ} \mathrm{C}$. Moreover, in these complexes the ligand GHL1 acts as a mononegative charge tridentate ligand and it is coordinated with the metal ions through $\mathrm{O}, \mathrm{N}, \mathrm{O}$ except with $\mathrm{Ni}(\mathrm{II})$ and $\mathrm{Cd}(\mathrm{II})$ complexes. The ligand behaves as a neutral bidentate which is coordinated with the metal ions through $\mathrm{O}, \mathrm{N}$ atoms.

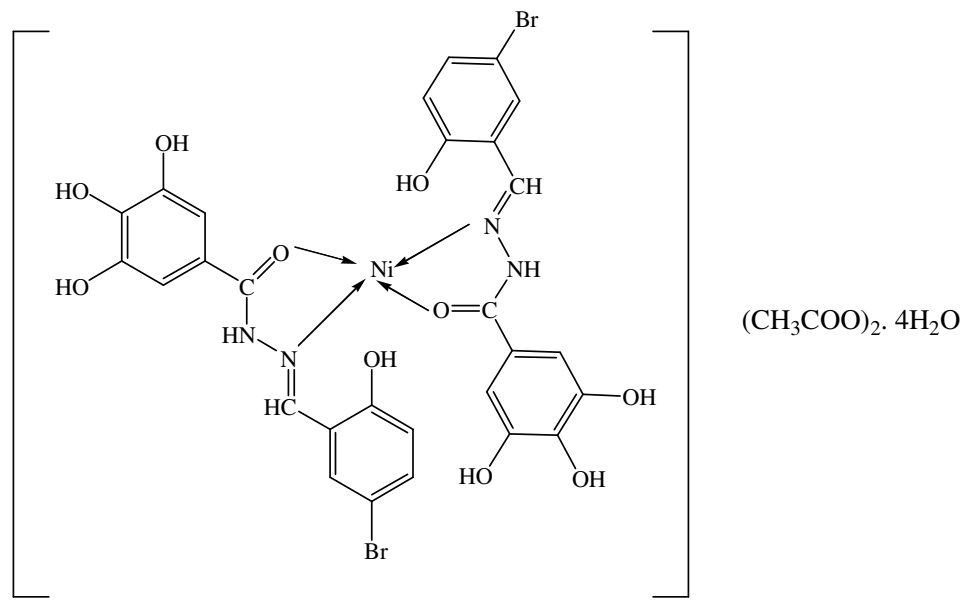

Figure 1. Proposed structure of $\left[\mathrm{Ni}(\mathrm{GHL1})_{2}\right]\left(\mathrm{CH}_{3} \mathrm{COO}\right)_{2} \cdot \mathrm{H}_{2} \mathrm{O}$.

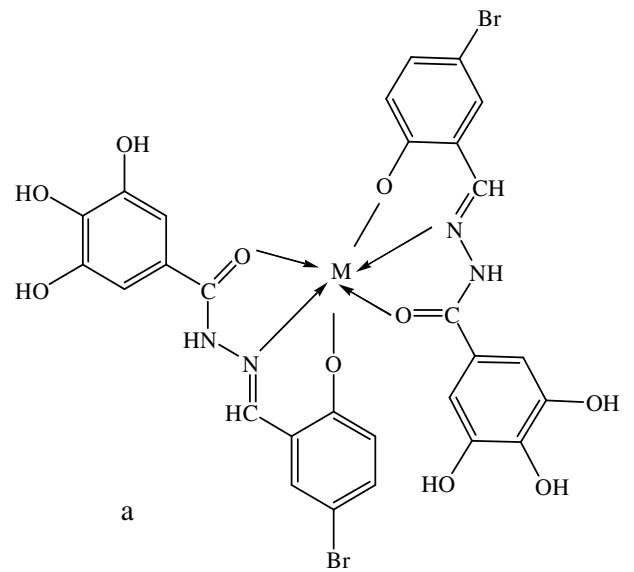<smiles>CC(=O)OC(C)(C)C12NN(Cc3cc(Br)ccc3O)C(C)(OC(C)O1)O2</smiles>

$\mathrm{M}=\mathrm{Cu}(\mathrm{II})$ and $\mathrm{Zn}(\mathrm{II})$

Figure 2. (a) Structure of $\left[\mathrm{M}(\mathrm{GHL} 1)_{2}\right]$ and (b) structure of $\left[\mathrm{Cd}(\mathrm{GHL} 1)\left(\mathrm{CH}_{3} \mathrm{COO}\right)_{2}\right] \cdot \mathrm{H}_{2} \mathrm{O}$. 


\section{ACKNOWLEDGEMENTS}

Thanks are due to University of Malaya for providing grants (PPP PS 252/ 2009 A). Additionally thanks to the staff members of Faculty of Science for their academic and technical assistance.

\section{REFERENCES}

1. Abu Affan, M.; Siong, W.F.; Ismail, J.; Sulaiman, H.; Edward, R.T.T. Inorg. Chim. Acta 2009, 362, 5031.

2. Antonio, S.P.; Nuria, C.; Jaime, R.; Maria, L.D.; José, A.G.; Antonio, S. Polyhedron 2008, 27, 3391.

3. Madalina, V.A.; Stefania, F.B.; Constantin, D.; Gabriela, L.A. Eur. J. Med. Chem. 2010, 45, 2055.

4. Vinuelas, E.Z.; Maldonado, M.A.; Luna, F.G.; Barros, F.J. Polyhedron 2008, 27, 879.

5. Ahmed, A.E. Inorg. Chim. Acta 2009, 362, 4991.

6. Mostafa, E.; Haifaa, E. Spectrochim. Acta Part A. 2007, 66, 28.

7. Sambuddh, B.; Susmita, M.; Writachit, C.; Soma, S.; Ratan, G.; Ray, J.B.; Alexandra, M. Z.; Slawin; Chitra, M.; Samiran, M. Polyhedron 2009, 28, 2785.

8. Deepak, S.; Lokesh, K.; Sulekh, C. Spectrochim. Acta Part A 2008, 71, 746.

9. Hamid, K.; Abeer, A.A.; Wagee, A.; Hapipah, M.A.; Mahmood, A.A.; Pouya, H. Archiv der Pharmazie - Chemistry in Life Science. 2010, ID: ardp. 201000223.R1 Wiley.

10. Abeer, A.A.; Hapipah, M.A.; Subramaniam, P.; Ward, T.R.; Seik, W.Ng. Acta Cryst. E. 2008, 64, o1584.

11. Shayma, A.S. E-J. Chem. 2010, 7(S1), S594.

12. Vidyavati, R.; Nirdosh, P.; Angadi, S.D. E-J. Chem. 2008, 5, 577.

13. Shayma, A.S.; Mohammed, H.A.; Abbas, A.S. Aust. J. Basic Appl. Sci. 2010, 4, 5178.

14. Shayma, A.S.; Yang, F. Am. J. Sci. Res. 2009, 5, 20.

15. Douglas, X.W.; Heloisa, B.; Amal, A.N.; Fathy, A.E.; Mohammed, I.A. Trans. Met. Chem. 1999, 24, 421.

16. Lever, A.B.P. Inorganic Electronic Spectroscopy, Elsevier: New York; 1968.

17. Shayma, A.S. E-J. Chem. 2010, 7, 1598.

18. Thahira, B.S.A.; Karen, A.C.; Ibrahim, M.T.; Andrew, R.C.; Akbar, M.A. Polyhedron 2007, $26,1159$.

19. Aljanabi, M.Y. The Physical Methods in Inorganic Chemistry, University of Baghdad: Iraq; 1983.

20. Shayma, A.S.; Hamid, K.; Hapipah, M.A. Chem. Papers 2011, 65, 299.

21. Cross, A.D.; Alan J. An Introduction to Practical Infrared Spectroscopy, Butterworths: London; 1969.

22. Dyer, R.J. Application of Absorption Spectroscopy of Organic Compounds, Prentice-Hall: New Jersey; 1965.

23. Socrates, G. Infrared Characteristic Group Frequencies, Wiely-Interscience: New York; 1980.

24. Abuelghar, M.F.; Abdelghani, N.T.; Badr, Y., Elborady, O.M. ISESCO Science and Technology Vision, 2007, 3, 58.

25. Efremov, V.A; Potolokov, V.N.; Nikolashin, S.V.; Fedorov, V.A. Inorg. Mater. 2002, 38, 837; translated from Neorganicheskie Materialy 2002, 38, 996. 